\title{
The Evaluation of the Relation Between Drug Compliance and Psychometric Tests in Chronic B Hepatitis Patients Who are Treated with Oral Antivirals
}

\author{
Oral Antiviral Tedavi Alan Kronik Hepatit B Hastalarında Ilaç Uyumunun Psikometrik \\ Testlerle llișkisinin Değerlendirmesi
}

\author{
๑ Esma Kepenek Kurt, ๑ Bahar Kandemir
}

Necmettin Erbakan University Meram Faculty of Medicine, Department of Infectious Diseases And Clinical Microbiology, Konya, Turkey

\begin{abstract}
Objectives: Hepatitis B is a viral infection that causes acute and chronic hepatitis and serious complications such as cirrhosis and hepatocellular cancer. Several psychiatric symptoms and depression, particularly anxiety, can be seen in patients. Evaluation of the relation between medication adherence and psychometric tests in patients with Chronic hepatitis $\mathrm{B}(\mathrm{CHB})$ who are treated with oral antivirals is aimed in this study.

Materials and Methods: Two hundred and fifty-nine patients were included in this study. Sociodemographic data form, Morisky 8 scale, Beck Anxiety scale (BAS) and Beck Depression scale (BDS) have been applied to the patients.

Results: The age of the patients vary from 17 to 80 , average age of the patients is foud as 46.04. A hundred eleven of the patients were women $(42.9 \%)$. Two hundred and seven patients had no sign of depression $(79.9 \%)$ and 52 of the patients $(20.1 \%)$ had depression. The drug compliance was low in patients whose BDS scores were decreased. It has been found out that 195 of the patients had lowgrade of anxiety (75.3\%), 26 of the patients had midgrade of anxiety $(10 \%)$, and 38 of the patients had high-grade of anxiety $(14.7 \%)$. The medication adherence was low in patients whose BAS scores were decreased.

Conclusion: Anxiety and depression are frequent in $\mathrm{CHB}$ patients. Therefore, CHB patients should be followed up psychiatrically and should be addressed to the psychiatry specialist when necessary. Depression and anxiety influences the drug compliance. Further studies are required for evaluation the relation between the medication adherence and the level of anxiety and depression in CHB patients.

Keywords: Hepatitis B, Depression, Anxiety, Adherence
\end{abstract}

$0 ̈ Z$

Amaç: Hepatit B, akut ve kronik hepatite yol açan siroz ve hepatoselüler kanser gibi ciddi komplikasyonlara neden olan viral bir enfeksiyondur. Kronik hepatit B (KHB) hastalarında birçok psikiyatrik semptom, depresyon ve özellikle anksiyete görülebilir. Bu çalışmada, oral antivirallerle tedavi edilen KHB'li hastalarda ilaç uyumunun psikometrik testlerle ilişkinin değerlendirilmesi amaçlanmıştır. Gereç ve Yöntemler: Çalışmaya 259 hasta dahil edildi. Hastalara sosyodemografik veri formu, Morisky 8 ölçek, Beck Anksiyete ölçeği (BAÖ) ve Beck Depresyon ölçeği (BDÖ) uygulanmıştır.

Bulgular: Hastaların yaşı 17 ila 80 arasında değişmekte olup, hastaların yaş ortalaması 46,04'tür. Hastaların $111^{\prime} \mathrm{i}(\% 42,9)$ kadındı. Iki yüz yedi $(\% 79,9)$ hastada depresyon belirtisi yoktu ve $52(\% 2,1)$ hastada depresyon vardı. Hastalarda BDÖ skorları azaldıkça ilaç uyumu düşüktü. Hastaların 195 'inde düşük dereceli anksiyete $(\% 75,3), 26$ 'sının orta dereceli anksiyete $(\% 10)$ ve $38^{\prime}$ inde yüksek anksiyete $(\% 14,7)$ düzeyine sahipti. Hastaların BAÖ skorları azaldıkça ilaç uyumu düşüktü.

Sonuç: KHB hastalarında anksiyete ve depresyon sıktır. Bu nedenle, KHB hastaları psikiyatrik olarak da izlenmeli ve gerektiğinde psikiyatri uzmanına yönlendirilmelidir. Depresyon ve anksiyete ilaç uyumunu etkiler. KHB hastalarında ilaç uyumu ile anksiyete ve depresyon düzeyi arasındaki ilişkinin değerlendirilmesi için ileri çalışmalar gereklidir.

Anahtar Kelimeler: Hepatit B, Depresyon, Anksiyete, Uyum

Kepenek Kurt E, Kandemir B. The Evaluation of the Relation Between Drug Compliance and Psychometric Tests in Chronic B Hepatitis Patients Who are Treated with Oral Antivirals. Viral Hepat J. 2019;25:92-96. 


\section{Introduction}

Hepatitis B virus (HBV) infections are a global public health problem. There is nearly 240 million HBV carrier in the world. Approximately 600.000 people die each year due to cirrhosis and cancer caused by HBV. In a meta-analysis conducted in Turkey, the prevalence of HBsAg was calculated as $4.5 \%$ (1).

Especially anxiety, several psychiatric symptoms, distress, difficulty in concentration of the thoughts, muscle strain, sleep disorders and depression may be seen in patients with chronic viral hepatitis (2). Medication adherence has been defined as the use of drugs by the patient in specified dose and time over a certain period of time (3). The symptoms of depression and anxiety may lead to low adherence to treatment, or may be resulted from low adherence to treatment (4).

Growing body of evidence reveals that, the incidence of psychiatric disorders is underestimated in patients with chronic hepatitis. Determination of depression and anxiety in CHB patients, and intervention when necessary are important for the success of treatment. Although there are many studies conducted on this issue, no any study could not find in the literature to investigate medication adherence, and the relationship of medication adherence with anxiety and depression in $\mathrm{CHB}$ patients receiving oral antiviral therapy. In this study, we aimed to evaluate medication adherence, and the relationship of medication adherence with anxiety and depression in $\mathrm{CHB}$ patients receiving oral antiviral therapy using Beck Anxiety scale (BAS) and Beck Depression scale (BDS).

\section{Materials and Methods}

This study was conducted in Infectious Diseases and Clinical Microbiology outpatient clinic between June 2014 and November 2014. Morisky Medication Adherence scale (MMAS-8) survey, BDS and BAS was applied on patients who were followed-up with the diagnosis of $\mathrm{CHB}$ and received oral antiviral therapy for $\geq 6$ months. Patients sex and age date were collected. Pregnants, patients with a history of using peg-interferon, a chronic disease leading to impairment in immune system, malignancy and collagen tissue disease, accompanying human immunodeficiency virus, positivity of $\mathrm{HCV}$ and HDV, those with the symptoms of decompensated liver cirrhosis, and patients with diagnosed psychiatric diseases were excluded from the study. After receiving approval from Necmettin Erbakan University Meram Faculty of Medicine Ethics Committee (approval number: 2014/687, date: 20.06.2014), the patients were interviewed. Informed consent form was received from patients. Volunteer patients applied sociodemographic data collection form, MMAS-8, BDS, BAS questionnaire.

Sociodemographic data collection form questioned patients' age, sex, duration of being infected with HBV, currently used drugs, duration of using the current drugs, and drugs used for comorbidities.

Morisky Medication Adherence scale-8: MMAS was developed by D.E. Morisky and its validity and reliability were studied by Morisky et al. (5). MMAS is a scale which evaluated drug use behaviours of the patient with 8 questions based on selfreport, and involves questions that will be enable a better evaluation of the obstacle which may cause medication nonadherence. It is an easy to fill scale. The questions are responded in the form of
"Yes/No". It is scored as 1 for Yes, and 0 for No. MMAS is scored between 0 and 8 . A score $<6$ has been defined as low adherence, $6-<8$ as medium adherence, and $\geq 8$ as high adherence. MTUÖ-8 is validity and reliability study for our country (6).

Beck Depression scale: BDS was developed in order to measure severity of depression, to enable follow-up experiences with treatment, and recognize the disease. Each sentence in BDS was numbered between 0 and 3 . The scale consists of 21 items that are listed from mild to severe form. It provided four-item Likert type measurement. BDS has been introduced as a self-report scale, which ask the patients evaluating their status for the last one week. For the severity, it is interpreted as $0-9=$ no/ninimal, 10-16=nild, $17-29=$ nedium, and 30-63=severe (7). The scale has been translated to Turkish as two distinct forms as BDI and BDS, and its validity and reliability were studied. The cut-off value of the scale was reported as 17 in validity and reliability study of the scale. BDS $<17$ points was considered as no depression, while BDS $>17$ indicated depression. In addition, depressive component burden increases with the score obtained from the scale (8).

BAS: BAS was developed by Beck et al. (9) in order to measure levels and severity of anxiety symptoms. BAS is a scale consisting of Likert type 21 items that involve four self-report item and is scored between 0-3. Anxiety levels of patients according to BAS scores have been classified as: 0-17 points low, 18-24 points medium, 25 or higher points as severe anxiety level. High scores of BAS indicate severity of depression and anxiety (10). The validity and reliability study in our country was done by Ulusoy et al. (11).

\section{Statistical Analysis}

The data were analyzed using SPSS version 21 software. Chi-square test was used in comparison of categorical variables. Normality of the numerical variables was analyzed with KolmogorovSmirnov test. Mann-Whitney $U$ test was used in the comparisons of numerical variables between two group. Whereas Kruskal-Wallis test was used in multiple groups. Spearman's rho correlation was used for deterination of the correlation between numerical variables. Crohnbach alpha coefficient was calculated for reliability analysis of the questionnaire. Frequency tables were prepared for the categorical variables. Descriptive values were visualized with relevant charts. $\mathrm{P}<0.05$ values were considered statistically significant.

\section{Results}

The mean age of 259 patients included in this study was $46.04 \pm 13.13$ years. Of all patients, 111 (42.9\%) were female and $148(57.1 \%)$ were male.

When CHB duration of 251 patients was evaluated, the mean duration of the disease was found as $10.22 \pm 7.39$ years. The remaining 8 patients did not know how long they were being infected with HBV. The mean duration of using drugs for hepatitis $B$ was found as $4.55 \pm 3.50$ years. A total of 255 patients were receiving oral antiviral therapy for mean $2.92 \pm 2.50$ years. Four patients did not know the duration of using drugs or left this question unanswered.

Of patients, 80 (30.9\%) were receiving tenofovir, 79 (30.5\%) telbivudine, 50 (19.3\%) entecavir, 45 (17.4\%) lamivudine, and 5 $(1.9 \%)$ adefovir. 
The mean MMAS-8 score was found as $3.28 \pm 1.54$ in all patients, $3.23 \pm 1.50$ in male patients, and $3.34 \pm 1.59$ in female patients. Medication adherence was statistically significantly higher in female than in male patients $(p=0.005)$. Standard questions used to determine adherence is shown in Table 1.

No significant correlation was found between patients' medication adherence and age distribution $(p=0.933)$, educationa status $(p=0.419)$, smoking $(p=0.796)$, alcohol abuse $(p=0.096)$, types of drugs used $(p=0.147)$, comorbidity $(p=0.818)$, and using additional drugs $(p=0.579)$.

The mean BDS was found as $11.16 \pm 9.66$ in all patients, $9.43 \pm 8.48$ in male, and $13.45 \pm 10.64$ in female patients. Fifty-two patients with high BDS, 22 (42.3\%) were male, and 30 (57.7\%) were female. BDS was statistically significantly higher in female than in male patients $(p<0.001)$, while no statistically significant correlation was found between age and BDS ( $p=0.086)$. There was a statistically significant correlation between patients' medication adherence and BDS score $(p=0.011)$. Medical adherence of the patients was higher as BDS decrease. Distribution of the patients adherence according to BDS is seen in Table 2

The mean BAS was found as $12.51 \pm 11.37$ in all patients, $9.51 \pm 8.82$ in male, and $16.51 \pm 13.09$ in female patients Looking to the relationship between sex and anxiety, BAS was statistically significantly higher in female compared with male patients ( $p<0.001)$, and no statistically significance correlation was found between age and BAS $(p=0.351)$. There was a statistically significant correlations between patients' medication adherence and BAI score $(p<0.001)$. Medication adherence was found to be lower as BAS decrease. Distribution of the patients' medication adherence according to BAS is seen in Table 3.

There was a statistically significant positive correlation between BDS and BAS of the patients $(p<0.001)(r=0.747)$.

\begin{tabular}{|c|c|c|}
\hline & No, $n(\%)$ & Yes, n (\%) \\
\hline 1. Do you sometimes forget to take medication? & $148(57.1)$ & $111(42.9)$ \\
\hline $\begin{array}{l}\text { 2. People sometimes miss taking their medicines for reasons other than forgetting. Thinking over the } \\
\text { past } 2 \text { weeks, were there any days when you did not take your medicine? }\end{array}$ & $175(67.6)$ & $84(32.4)$ \\
\hline $\begin{array}{l}\text { 3. Have you ever cut back or stopped taking your medicine without telling your doctor because you } \\
\text { felt worse when you took it? }\end{array}$ & $207(79.9)$ & $52(20.1)$ \\
\hline 4. When you travel or leave home, do you sometimes forget to bring along your medicine? & $202(78)$ & $57(22)$ \\
\hline 5. Did you take all your medicines yesterday? & $41(15.8)$ & $218(84.2)$ \\
\hline $\begin{array}{l}\text { 6. When you feel like your symptoms are under control, do you sometimes stop taking your } \\
\text { medicine? }\end{array}$ & $231(8.2)$ & $28(10.8)$ \\
\hline $\begin{array}{l}\text { 8. How often do you have difficulty remembering to take your medicine? } \\
\text { A: Never/Almost never, B: Occasionally, C: Sometimes, D: Usually, E: Always }\end{array}$ & $10(3.9)$ & $249(96.1)$ \\
\hline
\end{tabular}

Table 2. Distribution of adherence according to Beck Depression scale*

\begin{tabular}{|l|l|l|l|l|}
\hline & Without depression $\mathbf{n}(\%)$ & With depression $\mathbf{n}(\%)$ & Total & p value \\
\hline Low adherence & $193(82.1)$ & $42(17.9)$ & 235 & 0.011 \\
\hline Medium adherence & $12(60)$ & $8(40)$ & 20 & - \\
\hline High adherence & $2(50)$ & $2(50)$ & 4 & - \\
\hline Total & $207(79.9)$ & $52(20.1)$ & 259 & - \\
\hline *BDS: Beck Depression score & & & \\
\hline
\end{tabular}

Table 3. Distribution of adherence according to BAS*

\begin{tabular}{|l|l|l|l|l|l|}
\hline & Low & Medium & High & Total & p value \\
\hline Low adherence & $183(77.9)$ & $22(9.4)$ & $30(12.8)$ & 235 \\
\hline Medium adherence & $12(60)$ & $3(15)$ & $5(25)$ & 20 \\
\hline High adherence & 0 & $1(25)$ & $3(75)$ & 4 & 259 \\
\hline Total & $195(75.3)$ & $26(10)$ & $38(14.7)$ & 0.001 \\
\hline *BAS: Beck Anxiety scale & \multicolumn{5}{l}{} \\
\hline
\end{tabular}




\section{Discussion}

Studies have associated adherence to antiviral therapy with permanent virologic response, and low level of resistance in patients with $\mathrm{CHB}$ infection. One of the goals of $\mathrm{CHB}$ treatment is to obtain a high adherence with nükleoside analog (NAs). When 1 -year medication adherence was evaluated in $\mathrm{CHB}$ patients receiving NAs, the mean adherence was reported as $88 \% \pm 19 \%$ (12). Among 259 patients in our study, low adherence was found in $235(90.7 \%)$, medium adherence in 20 (7.7\%), and high adherence in $4(1.5 \%)$ patients. In our study, medication adherence rate was quite low. Whereas $\mathrm{CHB}$ patients are regularly followed-up and treated in our clinic. Since no significant increase was found in HBVDNA and liver enzyme levels of our patients at follow-up, we were thinking that these patients were using their drugs regularly. In addition, patients reported at follow-up that sometimes they forgot to take their drugs or forgot at least once in 2 weeks according to Morisky scale, which we used in the present study, and this might caused to evaluate the scale as noncompliant. However, lamivudine, adefovir, entecavir, and tenofovir are well-tolerated. In clinical studies, rate of termination of the treatment due to side effects within the first year is only $3 \%$ (12). We did not primarily associate the low rate of adherence in our study with side effects. Another factor, which may affect patients' adherence is the prevalence of disease in the society. Chronic disease such as HT and DM are more common and more symptomatic than $\mathrm{CHB}$ in general population. They progress with more serious complications such as stroke if left untreated. These complications are generally known in our society. For these reasons, rate of adherence might be low in majority of patients. Therefore, $\mathrm{CHB}$ patients should be emphatically instructed about that they should take their medicines everyday, and should regularly come to follow-ups even if they had no symptoms. Considering all studies in general, marked differences are seen among the methods used, study design, number of patients, treatment regimens administered, duraton of follow-up, definition of adherence, and methods measuring adherence. These differences explain the adherence varying in a such variable range.

Studies investigating medication adherence, and changes of attitudes toward using medication according to sex, have found no correlation between these two variables, while one study has found a correlation in favour of women (13). In our study, medication adherence was higher in female patients, and this might be related to that majority of female patients were housewives and they have more opportunity to attend controls during day.

Among the symptoms of hepatitis and liver diseases, psychiatric disorders may often be seen. Depression may also be seen during course of CHB (14). In a study by Inci (15) $22 \%$ of the patients were found to have scores of 17 or higher, which is the cut-off value of depression. In our study also $79.9 \%$ had no depression, and $20 \%$ had depression, consistently with the study by Inci (15) (22\%). BDI is not a psychiatric diagnostic test, and is a prediction test for the existence of depression. Therefore, patients with a high level of BDI were referred to psychiatry specialist for diagnosis and treatment.

Low expectation of sufficiency may lead to depression and anxiety or may be resulted from the symptoms of depression and anxiety. As a result, decrease in adherence level reduces self-efficacy and lead to decrease in medication adherence (16). In a review with 12 studies, patients with depression were found to be 3 times more nonadherent compared to patients without depression, and adherence was shown to be negatively affected by depression. In a study by Bautista et al. (17) with patients aged between 20-70 years in whom antihypertensive therapy was initiated, nonadherence to treatment developed within 3 months was found to be 2.5 folds higher in patients with mild depression, and 1.6 folds in patients with mild anxiety. Screening of the symptoms of depression and anxiety can be used to identify patients at high risk. Intervention targeting these conditions are essential to reveal increased adherence. In our study, patients' medication adherence was lower as BDI scores decreased. This might be resulted from low rate of adherence in vast majority of the patients. In addition, majority of our patients were male (57.1\%). Furthermore, medication adherence and BDI level were higher in female patients. Therefore, high medication adherence in women might be resulted from higher level of depression.

Anxiety is the most common symptom among psychiatric symptoms in CHB patients (14). In a study by Chan et al. (18) on 160 Chinese patients with $\mathrm{CHB}$, the rate of anxiety disorders was found as $14 \%$. In our study, patients were evaluated according to BAI, $75.3 \%$ had low, $10 \%$ medium, and $14.7 \%$ high level of anxiety. As is seen, anxiety scores or anxiety rates vary in a wide range among the studies. This difference can be attributed to nonhomogeneous groups, different methods used and differences in the number of patients.

In a study by Gois et al. (19) aiming to determine the relationship between adherence and measurements of depression and anxiety, high levels of depression and anxiety were demonstrated to be correlated with medication nonadherence. There are conflicting results about effects of anxiety disorders on medication adherence (20). In a study by Alcántara et al. (21) on 88 patients with uncontrolled $\mathrm{HT}$, investigating anxiety susceptibility index and effects of this on adherence to BP drugs, patients with a high anxiety susceptibility were found to be more noninherent to antihypertensive drugs compared with the patients with a low anxiety susceptibility. In a study about the relationship between emotional problems and treatment adherence of hemodialysis patients, anxiety, cognitive disorder and social support were associated with depression, although these factors were not associated with treatment adherence. The reason for absence of a correlation between treatment adherence and anxiety was attributed to that physical anxiety symptoms (sweating, dizziness, numbness) recorded in surveys are found in kidney disease or the other diseases (22). In this study, looking the results of different surveys anxiety was found in quarter and mild-to-moderate depression in $40 \%$ of the samples as in the prevalences of other studies (23). In our study, medication adherence was found to be lower as BAI scores decrease. This is associated with a high level of adherence because of concerns of the patients with anxiety about their health.

Depression may cause anxiety to develop in more than half of patients (24). In a study investigating the relationship between emotional problems and treatment adherence in patients receiving hemodialysis, high levels of depression were found to be associated with high levels of anxiety (25). In our study, a significant 
positive correlation was found between BAI and BDI scores. In a study by Cuhadaroğlu (26), it was stated that association of the symptoms of depression and anxiety shows parallelism with the diagnosis of depression from a descriptive perspective, and both conditions may be pathologies intertwined on the same line in terms of the pathogenesis.

\section{Conclusion}

Patients should be emphatically instructed by the physician about that should regularly come to follow-ups, and they should take their medicines regularly. Assoociation of anxiety and depression is often seen in $\mathrm{CHB}$ patients. Therefore, $\mathrm{CHB}$ patients should also be followed up psychiatrically, and should be referred to a psychiatry specialist if deemed necessary. In our study, conditions prone to pathology were found to increase medication adherence. Further studies should be conducted to evaluate the correlation of medication adherence with the levels of anxiety and depression. Further studies with larger groups of patients that will investigate medication adherence and nonadherence, reveal their causes and influencing factors are warranted.

\section{Ethics}

Ethics Committee Approval: After receiving approval from Necmettin Erbakan University Meram Faculty of Medicine Ethics Committee (approval number: 2014/687, date: 20.06.2014).

Informed Consent: Informed consent form was received from patients.

Peer-review: Externally peer-reviewed.

\section{Authorship Contributions}

Surgical and Medical Practices: E.K.K., B.K., Concept: E.K.K., B.K., Design: E.K.K., B.K., Data Collection or Processing: E.K.K., B.K., Analysis or Interpretation: E.K.K., B.K., Literature Search: E.K.K., B.K., Writing: E.K.K., B.K.

Conflict of Interest: Authors declare no conflict of interest.

Financial Disclosure: TThis study is generated from the first author thesis study.

\section{References}

1. Yamazhan T. Epidemiology of HBV Infection. In: Kandemir O, Danalioglu A (ed.). Hepatitis B-to-D Always Current Clinical Handbook. Istanbul, Viral Hepatitis Society; 2015;p.17-21.

2. Savaş N, Öner S, Tamam L, Oner H, Saltoglu N, Aytac N, Akbaba $\mathrm{M}$. Prevalence of anxiety and depression among patients with chronic hepatitis B followed up in clinical bacteriology and infectious diseases outpatient clinics of Cukurova University Medical Faculty Balcali Hospital. Flora. 2002;7:177-184.

3. Osterberg L, Blaschke T. Adherence to medication. NEJM 2005;353:487-497.

4. Stilley CS, Sereika S, Muldoon MF, Ryan CM, Dunbar-Jacob J. Psychological and cognitive function: Predictors of adherence with cholesterol lowering treatment. Ann Behav Med. 2004;27:117124.

5. Morisky DE, Green LW, Levine DM. Concurrent and predictive validity of a self-reported measure of medication adherence. Med Care. 1986;24:67-74.

6. Hacıhasanoglu Aşılar R, Gözüm S, Çapık C, Morisky DE. Reliability and validity of the Turkish form of the eight-item Morisky medication adherence scale in hypertensive patients. Anadolu Kardiyol Derg. 2014;14:692-700.

7. Aydemir O, Köroglu E. Clinical scales used in psychiatry. Physicians broadcasting association Ankara. 2006.p.346-353.

8. Hisli N. The validity and reliability of Beck Depression Inventory for University Students. J of Psychology. 1989;7:3-13.

9. Beck AT, Epstein N, Brown G, Steer RA. An inventory for measuring clinical anxiety: Psychometric properties. J Consult Clin Psychol. 1988;56:893-7.

10. Gülec H, Sayar K, Ozkorumak E. Somatic symptoms of depression. Turkish Journal of Psychiatry. 2005;16:90-96.

11. Ulusoy M, Sahin NH, Erkmen H. Turkish version of the beck anxiety inventory: Psychometric properties. J Cogn Psychother. 1998; 12:163-172.

12. Chotiyaputta W, Peterson C, Ditah FA, Goodwin D, Lok AS. Persistence and adherence to nucleos $(\mathrm{t})$ ide analogue treatment for chronic hepatitis B. J Hepatol. 2011;54:12-18.

13. Arpacı F, Acikel C, Simsek I. Drug use attitudes of a group of elderly people living in Ankara. TAF Prev Med Bull. 2008;7(6):51522.

14. Balcioglu G, Ozdemir S. Neuro-psychiatric Findings in Chronic Hepatitis Patients. In: Tabak F, Balık , Tekeli E (eds.), Viral Hepatitis 2005. Ankara, Viral Hepatitis Society 2005.p.76-82.

15. Inci $A$. The Investigation of the depression levels of chronic hepatitis B patients. Viral Hepat J. 2013;19:103-105.

16. Sacco WP, Wells KJ, Vaughan CA, Friedman A, Perez S, Matthew $\mathrm{R}$. Depression in adults with type 2 diabetes: The role of adherence, body mass index, and self-efficacy. Health Psychol. 2005;24:630-634

17. Bautista LE, Vera-Cala LM, Colombo C, Smith P. Symptoms of depression and anxiety and adherence to antihypertensive medication. Am J Hypertens. 2012;25:505-511.

18. Chan H, Yu CS, Li SY. Psychiatric morbidity in Chinese patients with chronic hepatitis B infection in a local infectious disease vlinic. East Asian Arch Psychiatry. 2012:22:160-168.

19. Gois C, Barbosa A, Ferro A, Santos AL, Sousa F, Akiskal H, Akiskal K, Figueira ML. The role of affective temperaments in metabolic control in patients with type 2 diabetes. J Affect Disord. 2011;134:52-58

20. Baldessarini RJ, Perry R, Pike J. Factors associated with treatment nonadherence among US bipolar disorder patients. Hum Psychopharmacol. 2008;23:95-105.

21. Alcántara C, Edmondson D, Moise N, Oyola D, Hiti D, Kronish IM. Anxiety sensitivity and medication nonadherence in patients with uncontrolled hypertension. J Psychosom Res. 2014;77:283-286.

22. Atencio BJ, Nucette E, Colina J, Sumalave S, Gómez F, Hinestroza D. Valuation of depression and anxiety in patients with chronic renal failure undergoing hemodialysis. Venezuelan Archives of Psychiatry and Neurology. 2004;50:35-41.

23. Vik SA, Maxwell CJ, Hogan DB. Measurements, correlates, and health outcomes of medication adherence among seniors. Ann Pharmacother. 2004;38:303-312.

24. Mineka S, Watson D, Clark LA. Comorbidity of anxiety and unipolar mood disorders. Annu Rev Psychol.1998;49:377-412.

25. Huertas-Vieco MP, Pérez-García R, Albalate $M$, de Sequera P, Ortega M, Puerta M, Corchete E, Alcázar. Psychosocial factors and adherence to drug treatment in patients on chronic haemodialysis. Nefrologia. 2014;17;34:737-742.

26. Cuhadaroglu F. Depression and Anxiety in Adolescents: A Research. Turkish Journal of Psychiatry. 1993:4:189-194. 